\title{
Pore Structure as a Determinant of Flexibility in Sustainable Lime-Cement Mortar Composites
}

\author{
Sule Adeniyi Olaniyan
}

\begin{abstract}
Flexibility of Lime Mortar resulting from its good permeability feature through its relatively large interconnected pore structure makes it popular as an old sustainable building material. This characteristic feature enhances its capability to suppress masonry deformation. However, its mechanical strength is weak. To address this shortcoming, cement is added to form a stronger composite. This study, therefore, evaluates the pore structure of the resulting lime-cement composite, with a view to assessing impact and sustainability of the lime's flexibility in the overall performance of the composite. Adopting equal mix ratio (1:3) of Binder/Aggregate $(\mathrm{B} / \mathrm{A})$, mortars were prepared using lime as a lone binder, as well as other five different compositions in the ascending and descending order of lime and cement binders (i.e., 1:1, 1:2, 1:3, 2:1 and 3:1). Each composition was assessed in fresh state using Water/Binder ratio, Air Content and Bulk Density. For the hardened state assessments, mechanical characteristics and microstructural features evaluated through six (6) and twelve (12) month curing periods respectively, were considered. Results of the investigation reveal that low cumulative porosity (i.e., summation of the porosities) across the three pore regions of Inter-Nano pores (1 - $10 \mathrm{~nm})$, Super-Nano pores $(10-100 \mathrm{~nm})$ and Sub-Micro pores $(0.1-1 \mu \mathrm{m})$, for each of the mortars, is observed to be synonymous with low cement content, low Modulus of Elasticity, low $\left(f_{c} / f_{f}\right)$, and thus, high flexibility. This observation is supported by high linear coefficient of correlation $\left(R^{2}=0.89\right)$ for the equation describing both 'cumulative porosity' (within the referenced three pore ranges) and cement content. Thus, it could be inferred that despite cement addition with resulting alteration in the pore structure of the composite, presence of lime would retain flexibility property of the composites, with more flexibility in the descending order of cement contents. Considering the impacts of pandemic climate change, growing energy costs and human activities on the environment, this study therefore attempts to promote revival of an old but partially abandoned sustainable lime based mortars, with a view to facilitating improved lime mortar performances, conservation of energy resources and overall protection of the environment.
\end{abstract}

Key words - Climate Change, Flexibility, Lime Mortars, Pore Structure, Sustainability.

\section{INTRODUCTION}

Lime mortar is an old but partially abandoned building material. It is obtained from mixing lime, sand and water together in a proportional ratio. It is a flexible and slow to harden material, thereby allowing minute movements within the mortar joints, without impacting negatively on the masonry's structural stability [1]-[4]. Its flexibility feature helps to cushion masonry joints, accommodate strains,

Submitted on September 14, 2021

Published on October 22, 2021.

Sule Adeniyi Olaniyan, Ladoke Akintola University of Technology, Nigeria.

(e-mail: saolaniyan@lautech.edu.ng) inhibit cracking, thereby resulting in good flexural bond strengths [5], [6]. It is characterised with low elastic modulus, and therefore capable of more deformation on load application compared with Portland cement [7]. Because of its relatively large interconnected pore structures, it has excellent permeability features. As a building fabric, these pore structures are responsible for the mortar's durability against environmental conditions as they accommodate growth of ice crystal within, in frost periods, without deteriorating the matrix [8], [9]. The permeability feature also reduces moisture entrapment within, a phenomenon known as "breathability" [8], [10]-[12]. Increased bond between mortar and substrate is facilitated through lime mortar's enhanced workability resulting from its high water retention property [5].

While the manufacture of limes requires less energy and releases lower greenhouse gases (about 20\% reduction, relative to Portland cement), most of the carbon dioxide released during its calcination is re-absorbed while exposed to the atmosphere as lime mortars, a process referred to as re-carbonation. This is in agreement with the current call for minimal energy consumption and reduced atmospheric $\mathrm{CO}_{2}$ concentration, with significant environmental usefulness [13]-[15]. Also, masonry laid with lime based mortar is characterised with lower bond strength (relative to cement) such that the masonry units can be prised off easily thereafter, thus encouraging material recycling, and hence, supporting overall sustainability. Additionally, building lime mortars finished structures do possess low thermal conductivity. This impacts positively on the interior surface temperatures of buildings and may therefore be considered for some insulating role [11], [16].

In general, lime mortar has several beneficial characteristics which may include good adhesion, ductility, useful porosity values [17] and therefore possesses greater water vapour permeability than Ordinary Portland Cement (OPC), which facilitates reduced moisture entrapment [18]. A lime binder facilitates good adhesion between surfaces, and ensures effective penetration into voids. Masonry joints would be cushioned to absorb strains, and therefore check cracking. It would constitute the primary route for moisture passage thereby making it permeable, to protect the overall structure. Thus, it acts sacrificially to protect the masonry units against the harmful impacts of salts and moisture [19]. However, in spite of these useful properties, lime mortar is known for long setting and hardening periods, low internal cohesion, high volumetric changes (i.e., shrinkage, particularly, aerial lime), relatively low mechanical strengths and a high water absorption capacity via capillarity. These have resulted in delayed project delivery periods leading to its relegation and relative disuse [20][22]. It is within this context that this experimental study has been carried out, to improve on lime mortar by replacing 
specific quantities of lime with cement with a view to evolving a performance synergy between lime and cement. In this case, their advantageous features are maximised at the expense of their individual shortcomings. Adding cement to lime mortar increases the mortar's strength. Alongside this is significant effect on the microstructural features of lime mortar as porosity, pore size distribution and vapour diffusion coefficient are progressively reduced (with increasing cement content) [23]. This may also lead to mortar's increased modulus of elasticity considered unfit to accommodate masonry deformations [3], [21], [25]-[27]. This study, therefore, focuses on the evaluation of the pore structures of the resulting lime-cement composites, with a view to assessing sustainability of the lime's flexibility on the overall performance of the evolving composite. This research has a potential to evolve a blended lime/cement mortar for improved mortar performance in new constructions, with attendant reduction on environmental impacts from construction industry.

\section{EXPERIMENTAL PROCEDURE}

\section{A. Materials and Mortar Preparation}

Considering material's availability, relatively short setting time to attain optimal strength, low handling difficulties, and the need to maximise lime performance behaviour [28], [29], Natural Hydraulic Lime (NHL-5.0) was adopted for this study. This was obtained from St Astiers, UK. Also, Cement (CEM I 52.5) for this study was supplied by 'Hanson Cement', UK. Particle Size Distributions for both Lime and Cement obtained using Laser Difractometry Xmastersize (via laser diffraction method) are indicated in Table I. Also, Chemical compositions (by elements) for both lime and cement as determined by Energy Dispersive Spectrometry are given in Table I. Siliceous fine kiln dried sand obtained from 'Fife Silica Sands', UK, constituted the aggregate. In line with the British Standards [30] and ASTM C 136 [31], the aggregate was passed through a sieve analysis as the particle size distributions are as shown in Fig. 1. The sand had Particle Size Distribution of 0-2 mm (i.e., $0.05 \mathrm{~mm}<\varnothing<2 \mathrm{~mm}$ ), considered suitable, in accordance with ASTM C 33 [32].

Considering binder-aggregate (B/A) ratio of 1:3 (by volume) being the most prevalent in the literature [20], [23], [34], [35], preparation of mortars followed requirements of British Standards [33]. To ensure measurement precision during batching, volume proportions of components were converted to weights [6]. Using BS EN 1015-3 [33] and BS
EN 1015-6 [36], workability of $145 \pm 5 \mathrm{~mm}$ was adopted for the mortars, to avoid stiffness or fluidity in accordance with the British Standards [37]. This was achieved through visual and physical assessments of the mixes during the trial experimentation.

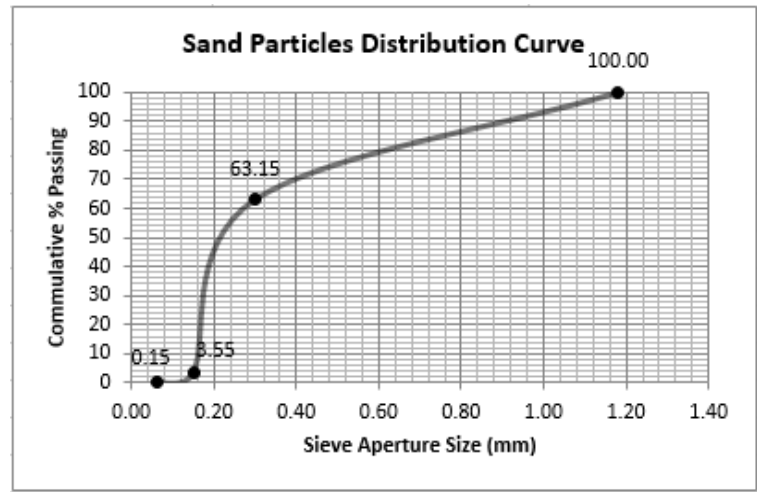

Fig. 1. Grain size distribution of the aggregate.

As shown in Table III, using the adopted B/A ratio (i.e., 1:3), mortars were prepared with increasing/decreasing cement contents. Mixing was done in the laboratory mixer of 30 litres maximum capacity as explained in previous studies [4], [28] and [38]. Three prismatic specimens of $40 \times 40 \times 160 \mathrm{~mm}$ was prepared for each mortar mix. An average value for the three was considered for the specimens during evaluations (i.e., for microstructural analysis, and mechanical characteristics evaluations). The specimens were compacted with a vibration table after mould filling in prismatic casts [39], demolded 2 days later and allowed to cure at the laboratory ambient conditions of $21+4{ }^{\circ} \mathrm{C}$ (temperature) and $40+5 \%$ (relative humidity), until the test dates of 1, 3, 6, 9 and 12 months.

\section{B. Analytical Methodology}

Details of the microstructural characteristics evaluation (in respect of the total porosity, median pore diameter, bulk density and pore size distribution, using Mercury Intrusion Porosimetry (MIP) technique via AutoPore IV 9500 by Micrometrics (with pressure range up to $60000 \mathrm{psi}$ )), mechanical properties assessment (using ELE AutoTest 2000 apparatus and INSTRON 3367) and some other relevant preliminary material testing (involving 'Carl Zeiss EVO 50' Scanning Electron Microscope and Laser Difractometry Xmastersize) are as documented in the previous studies [4], [28] and [38].

\begin{tabular}{ccccccc}
\multicolumn{7}{c}{ TABLE I: MATERIALS' PARTICLE SIZE DIAMETERS AS TESTED } \\
\hline Parameters & $\mathrm{d}(\mathrm{v}, 0.5)$ & $\mathrm{d}(\mathrm{v}, 0.1)$ & Mode & $\mathrm{d}(\mathrm{v}, 0.9) * *$ & $\begin{array}{c}\mathrm{D}[4,3] \\
\text { (main equivalent } \\
\text { diameter by volume) }\end{array}$ & $\begin{array}{c}\text { (main equivalent diameter } \\
\text { by Surface Area) }\end{array}$ \\
\hline $\begin{array}{c}\text { Specified } \\
\begin{array}{c}\text { Particle } \\
\text { Diameter }(\mu \mathrm{m})\end{array}\end{array}$ & Lime & 10.78 & 5.28 & 6.50 & 91.88 & 33.99 \\
\cline { 2 - 7 }
\end{tabular}

TABLE II: MATERIALS BY CHEMICAL COMPOSITIONS

\begin{tabular}{|c|c|c|c|c|c|c|c|c|c|c|c|c|}
\hline \multirow{2}{*}{ Material } & \multicolumn{12}{|c|}{ Materials' Chemical Compositions by Elements (by dry specimens' weight in \%) } \\
\hline & $\mathrm{Ca}$ & $\mathrm{O}$ & $\mathrm{Si}$ & $\mathrm{C}$ & $\mathrm{Sb}$ & $\mathrm{Al}$ & $\mathrm{Fe}$ & $\mathrm{Mg}$ & $\mathrm{S}$ & $\mathrm{K}$ & $\mathrm{Na}$ & $\mathrm{Ti}$ \\
\hline Lime & 47.6 & 37.6 & 5.2 & 4.4 & 3.3 & 0.7 & 0.5 & 0.5 & 0.2 & - & - & - \\
\hline Cement & 75.6 & 9.2 & 4.7 & - & 5.7 & 1.1 & 0.3 & 0.4 & 1.8 & 1.2 & 0.1 & - \\
\hline Sand & 0.2 & 53.5 & 43.0 & - & - & 1.6 & 0.4 & - & - & 1.1 & & 0.2 \\
\hline
\end{tabular}


TABLE III: LIME-CEMENT MORTARS COMPOSITIONS BY MATERIALS

\begin{tabular}{|c|c|c|c|c|c|}
\hline $\begin{array}{l}\text { Cement } \\
\text { Contents }\end{array}$ & $\begin{array}{l}\text { Mortar } \\
\text { Reference } \\
\text { I.D. (Slag } \\
\text { Contents) }\end{array}$ & $\begin{array}{l}\text { Volumetric } \\
\text { Ratio (L-C- } \\
\qquad \text { Sd) }\end{array}$ & $\begin{array}{l}\text { Lime (L): Volume } \\
\text { (Volume in 'ml'/ } \\
\text { mass in 'g') }\end{array}$ & $\begin{array}{c}\text { Cement }(\mathrm{C}) \text { : } \\
\text { Volume (Volume in } \\
\text { 'ml'/ mass in ' } \mathrm{g} \text { ') }\end{array}$ & $\begin{array}{l}\text { Sand (Sd): Volume } \\
\text { (Volume in 'ml'/ } \\
\text { mass in ' } \mathrm{g} \text { ') }\end{array}$ \\
\hline $0 \%$ & $\begin{array}{c}\text { L13 } \\
(0 \%)\end{array}$ & $1-0-3$ & $1(1700 / 1172)$ & $0(0)$ & $3(4350 / 6444)$ \\
\hline $25 \%$ & $\begin{array}{l}\text { LC31 } \\
(25 \%)\end{array}$ & $3-1-12$ & $3(770 / 528)$ & $1(415 / 442)$ & $12(4350 / 6444)$ \\
\hline $33 \%$ & $\begin{array}{l}\text { LC21 } \\
(33 \%)\end{array}$ & $2-1-9$ & $2(665 / 458)$ & $1(540 / 574)$ & $9(4240 / 6283)$ \\
\hline $50 \%$ & $\begin{array}{l}\text { LC11 } \\
(50 \%)\end{array}$ & $1-1-6$ & $1(850 / 586)$ & $1(830 / 883)$ & $6(4350 / 6444)$ \\
\hline $66 \%$ & $\begin{array}{l}\text { LC12 } \\
(66 \%)\end{array}$ & $1-2-9$ & $1(510 / 352)$ & $2(995 / 1060)$ & $9(3920 / 5800)$ \\
\hline $75 \%$ & $\begin{array}{l}\text { LC13 } \\
(75 \%)\end{array}$ & $1-3-12$ & $1(260 / 176)$ & $3(1250 / 1325)$ & $12(4350 / 6444)$ \\
\hline
\end{tabular}

\section{RESULTS AND DISCUSSION}

\section{A. Water/Binder (W/B) Ratio, Air Content and Bulk Density}

7Results of the W/B ratios for lime, and lime-cement mortars batched using varying binders' contents are shown in Fig. 2. A value of 1.53 was obtained for the reference mortar (lime mortar, L13), which indicates the ability of the mortar to retain water in the mix as it ensures plasticity and enhances workability [6], [41].

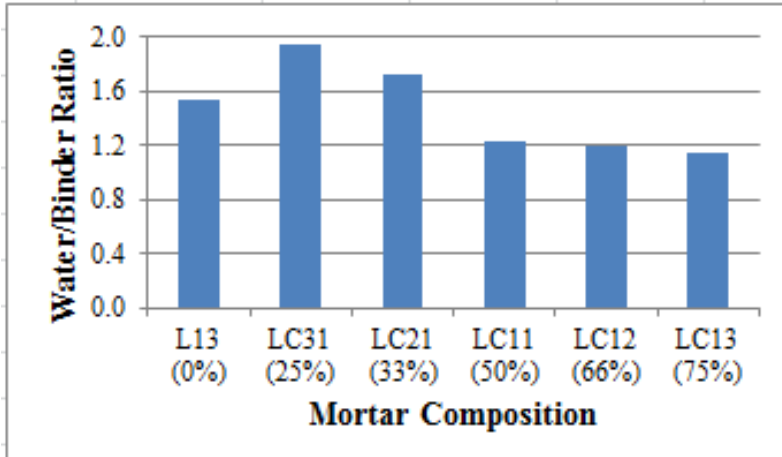

Fig. 2. Water/Binder ratios for lime mortars with increasing cement contents.

Adding cement content (to obtain the composites) reduces composites' water demand (although non-linear). This may result in quicker formation of more hydration products of Calcium Silicate Hydrates and subsequent densification of the mortar matrix [42] [43]. Concerning the mortars' Air Contents, the graph in Fig. 3 indicates air content value of $6.4 \%$ for lime mortar only.

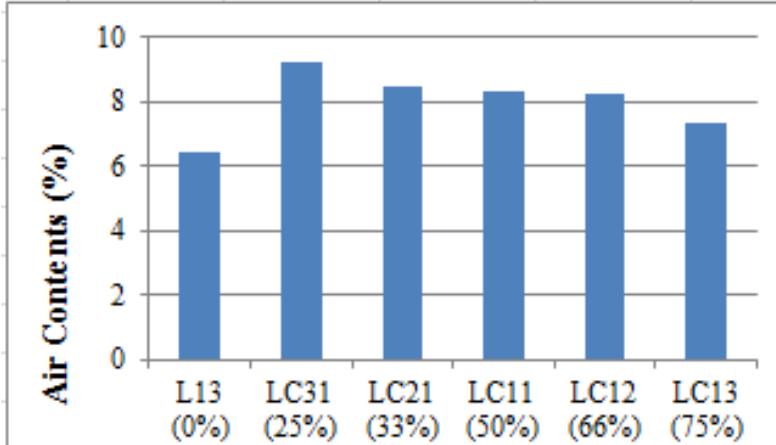

Mortar Composition (cement content)

Fig. 3. Air Contents for lime mortars with increasing cement contents.
With $25 \%$ addition of cement content to the mortar, air content value increased to $8.3 \%$. Further increase in cement content resulted in subsequent reduction of the air content due to densification of the microstructure, a consequence of hydration processes. During the hydration, the volume of pores is gradually reduced by the newly created products of the reactions, leading to formation of more compact composites, hence the observed air content reduction. Also, for lime only, the bulk density was $1.98 \mathrm{~g} / \mathrm{ml}$ (Fig. 4).

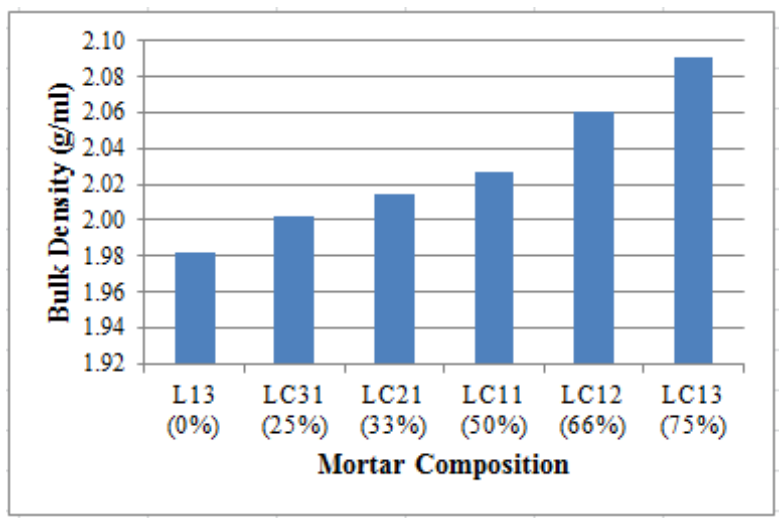

Fig. 4. Bulk Density for lime mortars with increasing cement contents.

The bulk density increases as more cement content is added, (although not in a complete linear trend). This may arise from deposition of $\mathrm{C}-\mathrm{S}-\mathrm{H}$ gel and other hydration products that are usually characterised with increase in mass. Hence, the more the cement content, the higher the bulk density. This is in agreement with the trend observed for the air contents.

\section{B. Microstructural Features}

Microstructural data inclusive of Pore Size Distribution (PSD) curves for the six different composites at 1 and 6 months of curing are as shown in Figs. 5 (a) and (b), and Table IV.

As shown in Fig. 5 (a), a bimodal PSD curve with predominant sizes between $(0.5-5 \mu \mathrm{m})$ and $(5-20 \mu \mathrm{m})$ is observed for lime only at first month of curing. The mortar displayed both gel pores (i.e., $1 \mathrm{~nm}-3 \mu \mathrm{m}$ ) and significant capillary pores (i.e., 3-30 $\mu \mathrm{m})$ [44]. Because of high waterretaining nature of lime, and its associated long carbonation process, the observed large pores arise from evaporation of excess unbound kneading water. The pores cannot be dissociated from fine cracks usually resulting from drying shrinkage which is capable of expanding and widening [4], 
[28]. Despite continuous carbonation at 6-months, wider pore range is prevalent, showing a presence of more pores with larger sizes (between $0.5 \mu \mathrm{m}$ and $40 \mu \mathrm{m}$ ) (Fig. 5 (b)). This is as a result of slow carbonation rate associated with hydraulic lime and possible effect of prevailing low relative humidity $(40 \pm 5 \%)$ in the laboratory curing conditions. Nevertheless, decrease in the total pore volume (i.e., from
27.77 to $23.42 \%$ ) is recorded during the curing period (Table IV). This shows replacement of some of the existing capillary voids by formation of the hydration and carbonation products (from hydraulic lime) over time. Also, arising from evaporation of excess kneading water and the drying shrinkage that accompanied that, the bulk density became reduced (from 1.75 to $1.72 \mathrm{~g} / \mathrm{ml}$ ).

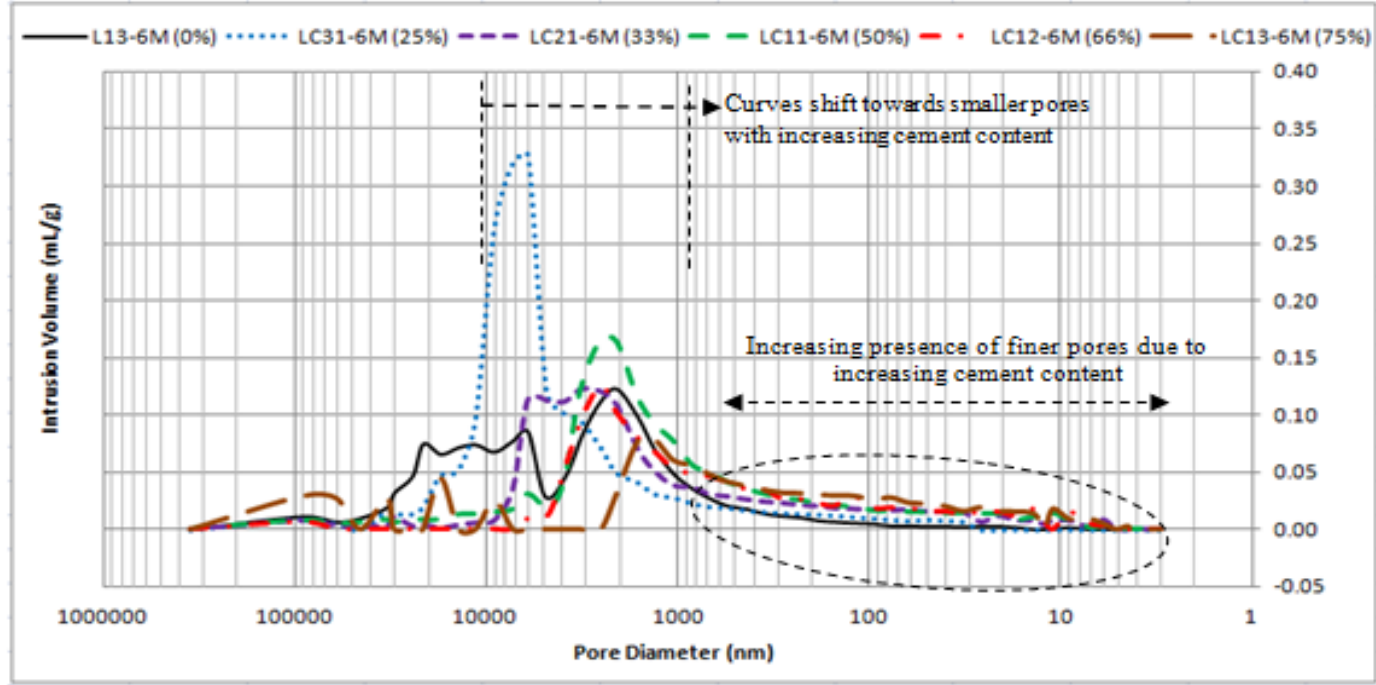

(a)

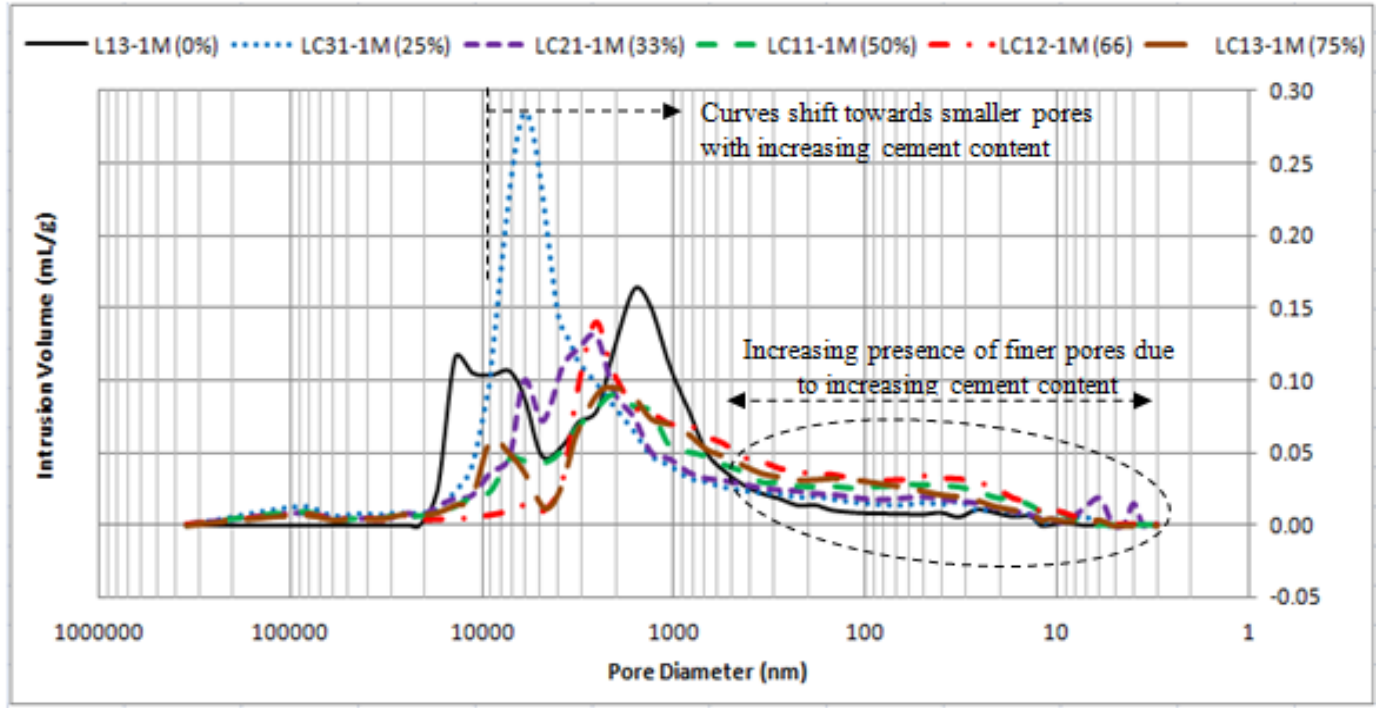

(b)

Fig. 5. Pore size distribution of lime mortars at different stages of curing: (a). At 1-month of curing; (b). At 6-month of curing.

TABLE IV: MICROSTRUCTURAL DATA FOR VARIOUS COMPOSITE MORTARS

\begin{tabular}{ccccc}
$\begin{array}{c}\text { Specimen } \\
\text { Reference } \\
\text { I.D. }\end{array}$ & $\begin{array}{c}\text { Curing } \\
\text { Period }\end{array}$ & $\begin{array}{c}\text { Median Pore } \\
\text { Diameter } \\
\text { (Volume) } \\
{[\mathrm{nm}]}\end{array}$ & $\begin{array}{c}\text { Bulk } \\
\text { Density at } \\
0.52 \text { psia } \\
{[\mathrm{g} / \mathrm{mL}]}\end{array}$ & $\begin{array}{c}\text { Porosity } \\
{[\%]}\end{array}$ \\
\hline L13 & 1 Month & 2163.6 & 1.75 & 27.77 \\
$(0 \%)$ & 6 Months & 3955.0 & 1.72 & 23.42 \\
LC31 & 1 Month & 4276.0 & 1.78 & 29.17 \\
$(25 \%)$ & 6 Months & 6616.9 & 1.80 & 30.03 \\
LC21 & 1 Month & 3036.1 & 1.78 & 27.54 \\
$(33 \%)$ & 6 Months & 2579.4 & 1.84 & 23.43 \\
LC11 & 1 Month & 1487.3 & 1.83 & 24.35 \\
$(50 \%)$ & 6 Months & 1909.7 & 1.87 & 25.67 \\
LC12 & 1 Month & 989.4 & 1.86 & 25.51 \\
$(66 \%)$ & 6 Months & 1340.8 & 1.92 & 20.81 \\
LC13 & 1 Month & 1372.1 & 1.86 & 24.64 \\
$(75 \%)$ & 6 Months & 1033.7 & 1.90 & 21.45 \\
\hline
\end{tabular}

On the contrary, addition of cement to the mortar resulted in unimodal PSD curve with narrow pore range, reduced intrusion peaks and presence of finer pores at 1 and 6 months (Fig. 5 (a) and (b)). This can be attributed to lower $\mathrm{W} / \mathrm{B}$ ratio due to reduction in lime content in the composite, faster hydration associated with cement and subsequent replacement of larger pores by $\mathrm{C}-\mathrm{S}-\mathrm{H}$ gel and other hydration products [45]-[47]. This may account for the observed densification of the mortar matrixes, reduced porosities, and prevalence of smaller pore sizes in lime mortar due to the addition of cement. Usually, quantity of kneading water becomes lower as cement content in the paste becomes higher (as observed in Section 3.1). The curves are therefore shifted towards the right (relative to lime mortar), which shows dominance of smaller pores (10- 
$500 \mathrm{~nm}$ range). These observations are clearly shown in Fig. 6 as the pronounced effects between lime mortar (L13) and the composite having the highest cement content (LC13) at 6-month of curing are comparably illustrated.

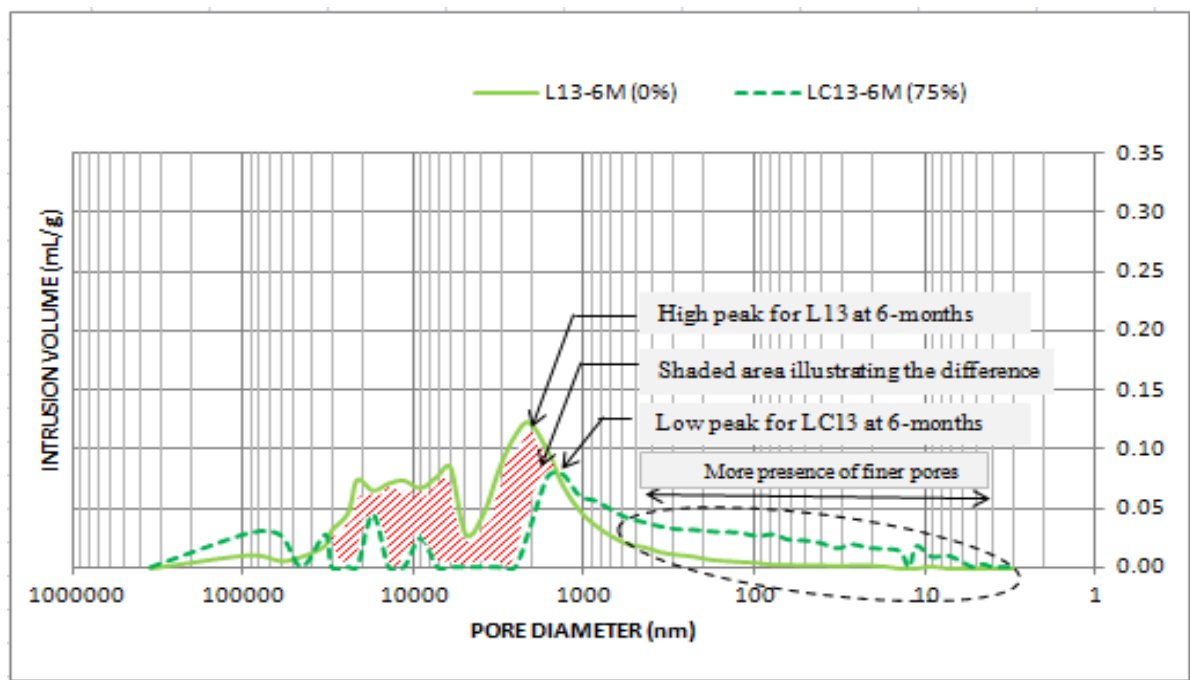

Fig. 6. Changes in the Pore Size Distribution curves of lime and composite mortars at 6-month curing.

The observed reduced intrusion peak and dominance of finer pores can be related to replacement of larger pores by $\mathrm{C}-\mathrm{S}-\mathrm{H}$ gel and other hydration products, leading to presence of more smaller pore sizes and consequent reduced porosity in lime mortar. In particular, porosity is reduced by about $8 \%$ in LC13 over the 6-month period.

Results of the Total Water Absorption of the mortars are shown in Fig. 7, to further assess the mortars' microstructural features. For lime only (L13), water absorption values were $13.84 \%$ and $13.68 \%$ at 1 and 12 months of curing respectively. This reduction relates to continuous formation of hydration and carbonation products from the hydraulic lime, leading to porosity reduction.

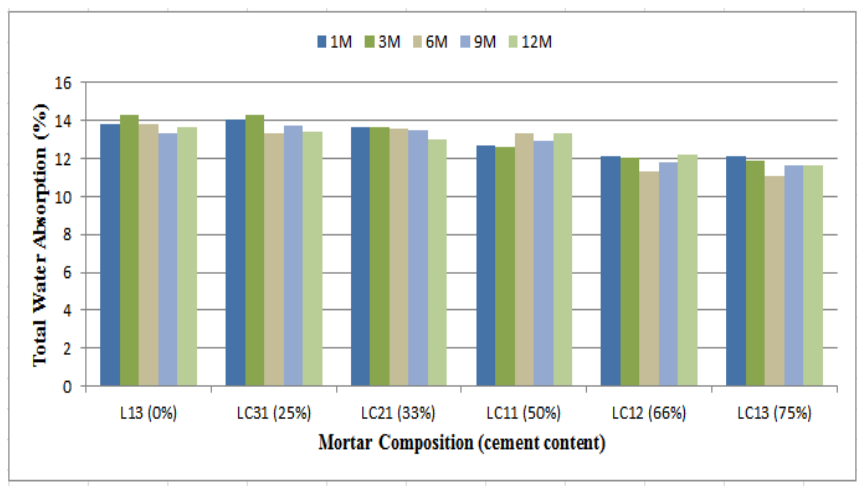

Fig. 7. Total Water Absorption for lime mortars added with cement.

Progressive addition of cement results in relatively small but steady reduction in the total water absorption, leaving LC13 at $11.68 \%$ over 12 months. It can be inferred that addition of cement to lime mortar induced modification of the mortar microstructures with a reduction in porosity over time. This decrease in the pore volume is the result of filling of larger pores in lime mortar by the cement hydration products, particularly Calcium Silicates. Consequently, there is more restriction on water movements, leading to the observed reduced water absorption pattern (Fig. 7). However, within each mortar mix, reduction pattern in water absorption was low. This may also be associated with suspected low carbonation of the mortars after the initial hydration.

\section{Mechanical Properties}

Table V summarises results of the flexural strength, compressive strength, and modulus of elasticity, for the mortars over a 12-month curing period. Each result was obtained from the average of three similar specimens for flexural strength, and five similar specimens for both compressive strength and modulus of elasticity each. It could be noted that the Coefficients of variation (COV) fall substantially within the lower range $(0-17 \%)$ with few outliers, however. This generally suggests consistent results.

For lime only, decrease in the flexural strength is observed (0.70 Mpa and 0.61 Mpa at the first and twelfth months of curing). This may result from formation of different pore sizes due to evaporation of excess unbound kneading water as observed in the microstructural analyses above. Progressive addition of cement to the mortar, raised the values for the flexural strength throughout the curing period, although not in a linear trend. This is because quicker hydration process, faster formation of C-S-H gel, reduced pore sizes and volume, associated with Cement, increased the flexural strength at a relatively shorter rate. This is applicable to all the composites. In this regard, of particular reference is LC12 which recorded the highest values of $4.12 \mathrm{Mpa}$ and $4.23 \mathrm{Mpa}$ at 1 month and 12 months of curing, respectively.

Compressive strength developments follow similar trends with the flexural strength. For lime only, compressive strength recorded $0.61 \mathrm{Mpa}$ and $0.66 \mathrm{Mpa}$ at 1 month and 12 months respectively. This marginal increase may also result from formation of different pore sizes resulting from evaporation of excess unbound kneading water as shown in the microstructural analyses above. As expected, these values significantly increased with increasing contents of cement. Highest values of 9.17 Mpa and 12.34 Mpa were recorded at 1 and 12 months of curing, for the mix with triple cement contents (LC13). Compared with the mix with no cement content (L13) over the same curing period, this represents a significant increase (in each case) above. 
TABLE V: Mechanical StRENGTH DeVElopments FOR LiME AND LiME-CEMENT MORTARS OVER 12-MONTH CuRING PERIOD

\begin{tabular}{|c|c|c|c|c|c|c|c|}
\hline \multirow{2}{*}{$\begin{array}{c}\text { Mortar } \\
\text { Reference } \\
\text { I.D. }\end{array}$} & \multirow{2}{*}{$\begin{array}{c}\text { Volumetric } \\
\text { Ratio } \\
\text { (L-C-Sd) }\end{array}$} & \multirow{2}{*}{$\begin{array}{c}\text { Mechanical Parameters } \\
(\mathrm{MPa})\end{array}$} & \multicolumn{5}{|c|}{ Curing Period (month(s)) } \\
\hline & & & 1 & 3 & 6 & 9 & 12 \\
\hline \multirow{3}{*}{$\begin{array}{l}\mathrm{L} 13 \\
(0 \%)\end{array}$} & \multirow{3}{*}{$1-0-3$} & Flexural (COV (\%)) & $0.70(6)$ & $0.54(4)$ & $0.63(0)$ & $0.63(6)$ & $0.61(0)$ \\
\hline & & Compressive (COV (\%)) & $0.63(6)$ & $0.59(5)$ & $0.68(15)$ & $0.68(4)$ & $0.66(6)$ \\
\hline & & $\begin{array}{l}\text { Modulus of Elasticity (COV } \\
(\%))\end{array}$ & $181.47(5)$ & $136.73(16)$ & $175.46(30)$ & $107.71(11)$ & $93.08(28)$ \\
\hline \multirow{3}{*}{$\begin{array}{l}\text { LC31 } \\
(25 \%)\end{array}$} & \multirow{3}{*}{$3-1-12$} & Flexural $(\mathrm{COV}(\%))$ & $1.13(6)$ & $1.27(10)$ & $1.13(9)$ & $1.06(14)$ & $1.16(13)$ \\
\hline & & Compressive (COV (\%)) & $1.88(5)$ & $1.65(25)$ & $2.86(14)$ & $2.26(14)$ & $2.57(5)$ \\
\hline & & $\begin{array}{c}\text { Modulus of Elasticity (COV } \\
(\%) \text { ) }\end{array}$ & $382.75(6)$ & $382.53(18)$ & $487.68(6)$ & $443.32(6)$ & $416.10(14)$ \\
\hline \multirow{3}{*}{$\begin{array}{l}\mathrm{LC} 21 \\
(33 \%)\end{array}$} & \multirow{3}{*}{$2-1-9$} & Flexural $(\mathrm{COV}(\%))$ & $1.52(5)$ & $1.27(15)$ & $1.52(5)$ & $1.60(3)$ & $1.29(4)$ \\
\hline & & Compressive (COV (\%)) & $2.64(9)$ & $2.33(16)$ & $2.53(12)$ & $3.76(6)$ & $3.10(14)$ \\
\hline & & $\begin{array}{c}\text { Modulus of Elasticity } \\
(\text { COV }(\%))\end{array}$ & $405.02(9)$ & $481.46(9)$ & $524.15(12)$ & $528.21(3)$ & $476.86(6)$ \\
\hline \multirow{3}{*}{$\begin{array}{r}\mathrm{LC} 11 \\
(50 \%)\end{array}$} & \multirow{3}{*}{$1-1-6$} & Flexural (COV (\%)) & $2.57(24)$ & $2.92(3)$ & $2.91(4)$ & $2.71(5)$ & $2.84(12)$ \\
\hline & & Compressive (COV (\%)) & $5.83(6)$ & $5.27(11)$ & $8.21(17)$ & $6.36(4)$ & $8.58(4)$ \\
\hline & & $\begin{array}{l}\text { Modulus of Elasticity (COV } \\
(\%))\end{array}$ & $631.89(2)$ & $604.78(6)$ & $671.51(5)$ & $627.62(2)$ & $683.58(1)$ \\
\hline \multirow{3}{*}{$\begin{array}{l}\mathrm{LC} 12 \\
(66 \%)\end{array}$} & \multirow{3}{*}{$1-2-9$} & Flexural (COV (\%)) & $4.12(9)$ & $3.71(13)$ & $4.14(8)$ & $3.83(3)$ & $4.23(2)$ \\
\hline & & Compressive (COV (\%)) & $8.24(4)$ & $9.45(7)$ & $10.45(4)$ & $11.34(8)$ & $10.52(5)$ \\
\hline & & $\begin{array}{l}\text { Modulus of Elasticity (COV } \\
(\%))\end{array}$ & $633.61(5)$ & $701.02(1)$ & $691.50(3)$ & $719.96(2)$ & $681.81(2)$ \\
\hline \multirow{3}{*}{$\begin{array}{l}\mathrm{LC} 13 \\
(75 \%)\end{array}$} & \multirow{3}{*}{$1-3-12$} & Flexural $(\mathrm{COV}(\%))$ & $3.47(5)$ & $3.56(15)$ & $4.40(0)$ & $3.74(11)$ & $4.01(1)$ \\
\hline & & Compressive (COV (\%)) & $9.17(9)$ & $9.19(4)$ & $12.85(11)$ & $9.38(6)$ & $12.34(5)$ \\
\hline & & $\begin{array}{l}\text { Modulus of Elasticity (COV } \\
(\%))\end{array}$ & $685.49(2)$ & $698.41(3)$ & $780.83(2)$ & $683.30(3)$ & $717.74(3)$ \\
\hline
\end{tabular}

As revealed in the values obtained for their moduli of elasticity (E), mortars' practical performance is related to the compressive strength recorded in each case. From Table $\mathrm{V}$, after 12 months of curing, lowest 'E' value was recorded for L13 with the lowest compressive strength. Conversely, over the same curing period, the mix with the highest compressive strength, $\mathrm{LC} 13$, recorded the highest ' $\mathrm{E}$ ' value. Nonetheless, both mixes have the tendencies to exhibit contrasting elastic behaviours (high and low respectively), as revealed in their stress-strain relationships at 1, 3, 6, 9 and 12 months of curing (Fig. 8 (a) to (e)), with varying capacities to absorp deformation. The pattern is also applicable to the other mixes. From the figures, as the slope of the curve becomes smaller, the better the elastic behaviour. Every mortar exhibits comparably varying slopes relative to lime mortar's (L13). Compressive stress relates proportionally with increase in the content of cement as reflected on the behavioural patterns for the individual composites (Fig. 8 (a) to (e)). The specimen having the highest cement content (i.e., LC13 with 75\% cement content) for example, sustained about $8 \mathrm{Mpa}$ and $12 \mathrm{Mpa}$ maximum compressive stresses after 1 and 12 months respectively. This is at variance significantly with LC 31, the composite having the least cement content (i.e., having 25\% cement content), capable of sustaining maximum compressive stresses of $2 \mathrm{Mpa}$ and $3 \mathrm{Mpa}$ only, over the same period respectively. Generally, increase in cement content is associated with higher slope of the curve. This is characterised with negative consequences on the strain, thereby reducing the ability of the sample to sustain deformation. This leads to decrease in flexibility. Thus, as LC13 curve is observed with the highest gradient, it is characterized with the least flexibility, and consequently, the least capability to sustain deformation before failure. This observation is further supported with the mortars' Compressive/Flexural strength ratios $\left(f_{c} / f_{f}\right)$, and Moduli of Elasticity relationships, with increasing cement contents as demonstrated in Fig. 9.
Fig. 9 confirms that the lower the E-value, so also the lower the $\left(f_{d} / f_{f}\right)$ ratio, and the higher the flexibility of mortars. These descriptions are in agreement with the studies by [48] and [49], indicating that mortar's ' $E$ ' value is inversely proportional to its elastic behaviour.

\section{Further Result Analyses: Examining the Pore Structures}

From Figs 8 (a)-(e), the patterns show by the composites indicate that they are relatively characterized by elastic behaviours compared with the basic lime-based mortar (specimen L13). To ascertain these behaviours, since nano structural and colloidal characteristics of lime, and the carbonation process by which it hardens strongly influence the ultimate performance of lime mortars [28], mortars' pore structures were examined through further analyses of their MIP results. Since porosity is measured directly by a volume of mercury intrusion into the specimen, volumes of intruded mercury for corresponding pore ranges were subdivided into six pore size classifications and ranges (as recognised/applicable to AutoPore MIP software) in order to obtain total porosity for each range, as indicated in Table VI.

TABLE VI: ADOPTED CLASSIFICATION AND PORE RANGE

\begin{tabular}{cccc}
\hline S/N & $\begin{array}{c}\text { Pore Size } \\
\text { Classification }\end{array}$ & $\begin{array}{c}\text { Adopted } \\
\text { Acronym** }\end{array}$ & Pore range \\
\hline 1 & Inter-Nano pores & $\mathrm{INp}$ & $1-10 \mathrm{~nm}$ \\
2 & Super-Nano pores & SNp & $10-100 \mathrm{~nm}$ \\
3 & Sub-Micro pores & SMp & $0.1-1 \mu \mathrm{m}$ \\
4 & Inter-Micro pores & $\mathrm{IMp}$ & $1-10 \mu \mathrm{m}$ \\
5 & Super-Micro pores & SuMp & $10-100 \mu \mathrm{m}$ \\
6 & Sub-Milli pore & SMip & $>100 \mu \mathrm{m}$ \\
\hline
\end{tabular}

Source: MIP AutoPore software.

Note: ** - Acronym adopted solely for this analysis. 


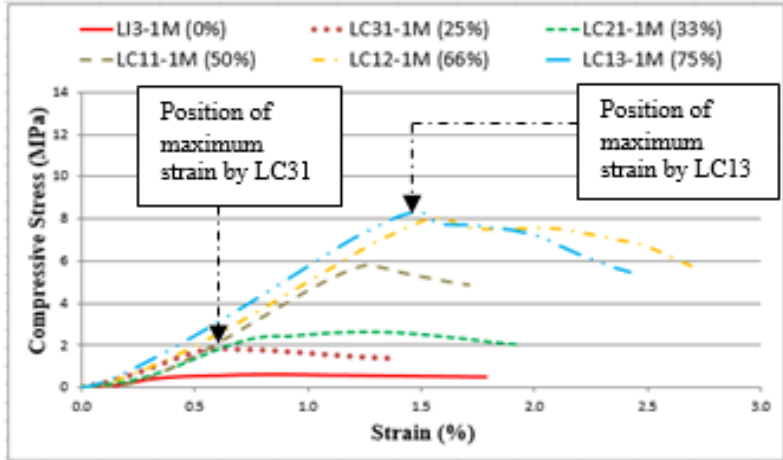

(a)

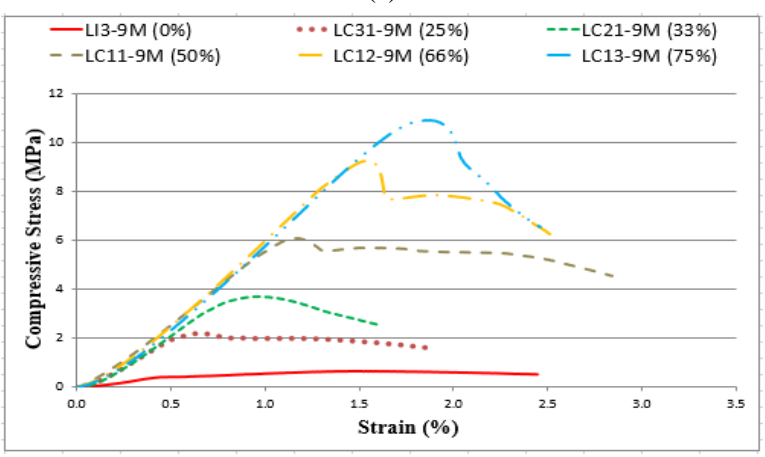

(c)

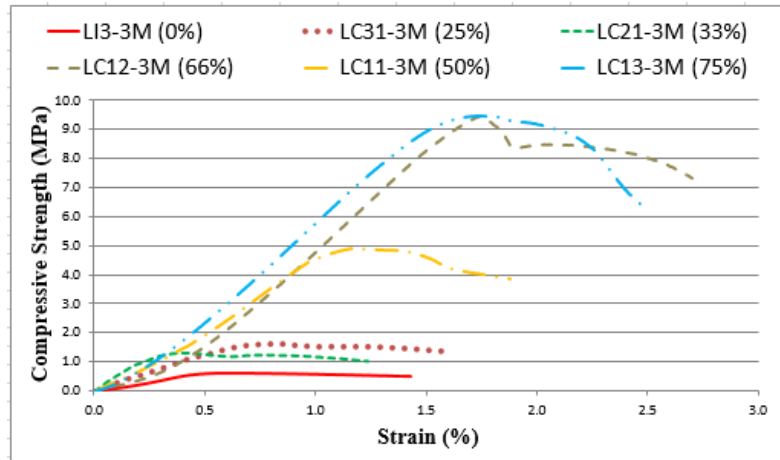

(b)

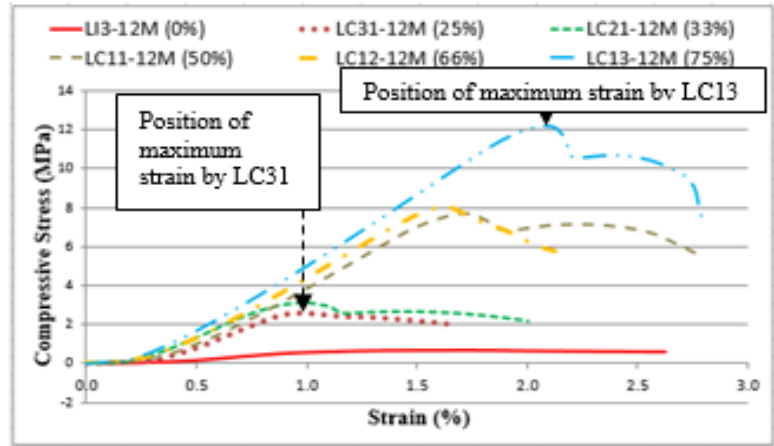

(d)

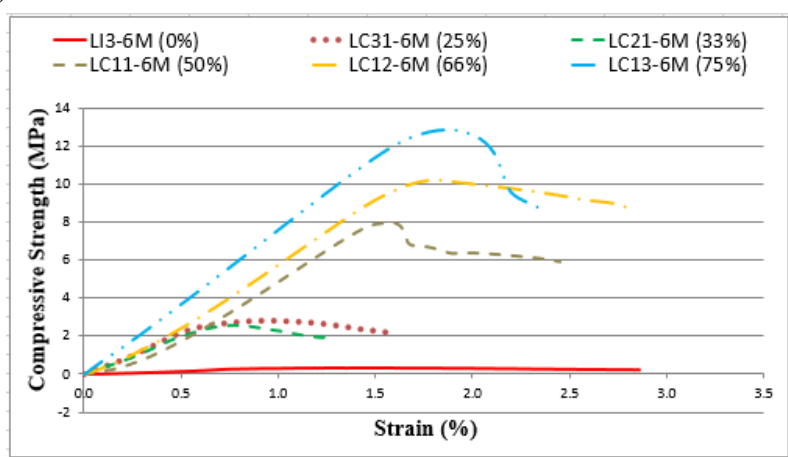

(e)

Fig. 8. Compressive Strength /Strain relationships for lime and composite mortars over a 12-month curing period: (a) At 1-month curing; (b) At 3-month curing; (c) At 6-month curing; (d) At 9-month curing; (e). At 12-month curing.

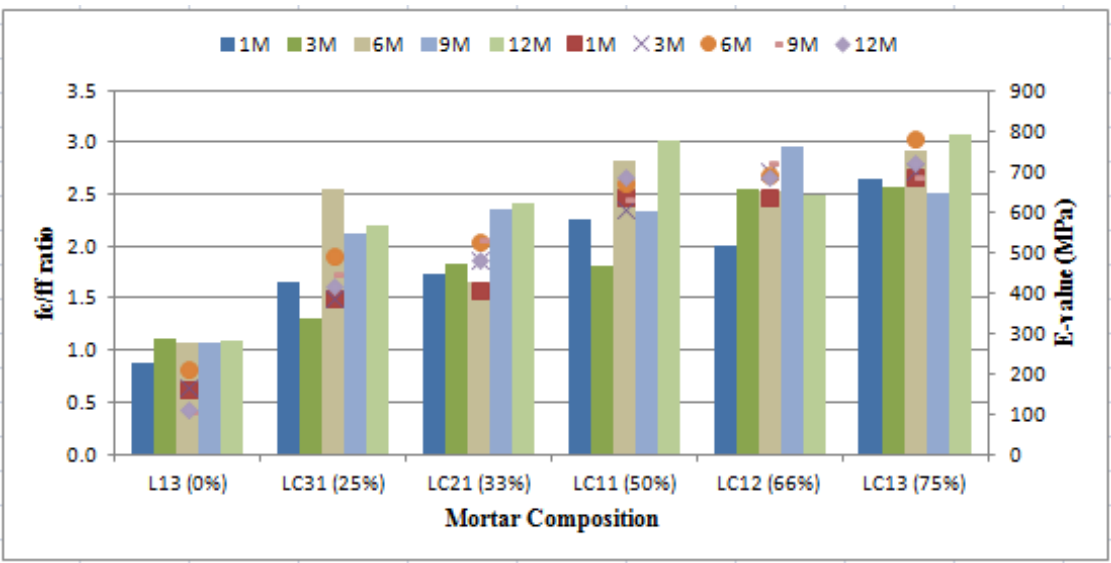

Fig. 9. Compressive/Flexural strength ratios $\left(f_{d} / f_{f}\right)$ versus Moduli of Elasticity for lime and composite mortars over a 12-month curing period (general relationships).

Lime porosity with interconnected pores facilitate its ability to meet opposing moisture movement requirements of breathability in the large pores and capillary transport in the small pores [19]. Following the classifications in Table VI, lime's predominant pore range is notably within SubMicro pores (SMp) and Inter-Micro pores (IMp) regions, the regions that are effective for moisture movement. This is important for dissolution of $\mathrm{CO}_{2}$ and eventual carbonation reactions. Fig.10 therefore shows volumes of intruded mercury for each pore range (based on the classification in Table VI) in all the mortar samples. The data were collected after 6-months of curing.

Since the study is primarily based on B/A ratio of $1: 3$, sample L13 (lime only, with 0\% cement content) is used as 
the reference sample for the comparative analyses. Referencing Fig. 10, the dotted line indicates direction (downward) of higher cumulative porosity (i.e., summation of the porosities) in the first three pore regions of Inter-Nano pores (1-10 nm), Super-Nano pores (10-100 nm) and SubMicro pores $(0.1-1 \mu \mathrm{m})$, for each of the mortars. Low cumulative porosity across the first three pore regions in a mortar is observed to be synonymous with low cement content, low Modulus of Elasticity, low (fc/ff), and thus, high flexibility. This observed trend as noted in Fig. 10 is well stated in Table VII.

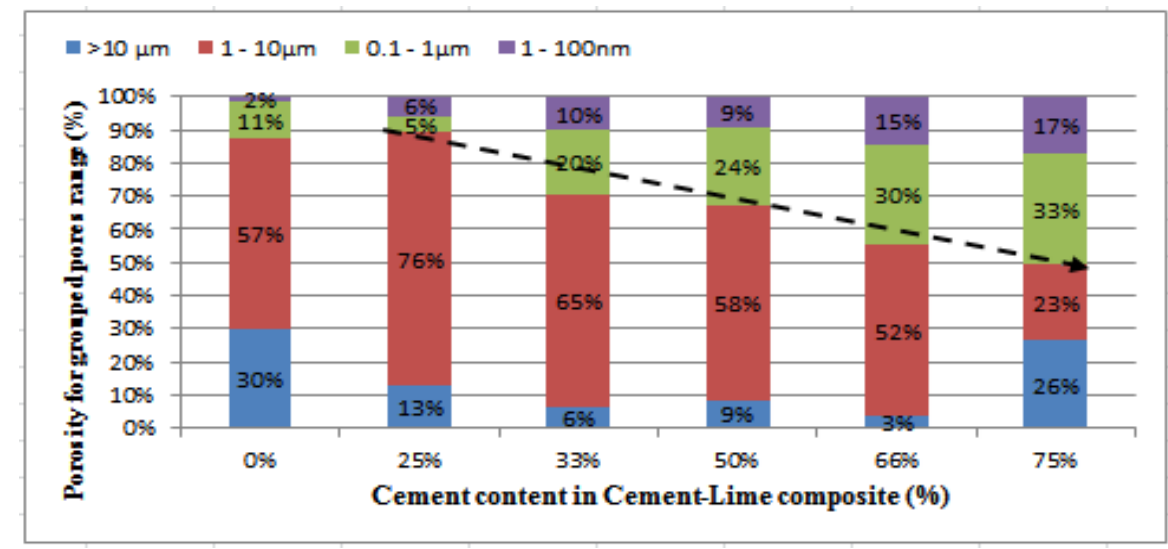

Fig. 10. Individual six-level pore size classifications with intruded mercury volume for lime and lime-cement mortars.

TABLE VI: EXTRACTED MIP AND E-VAlue DATA FOR Lime AND Lime-Cement MoRTaRs

\begin{tabular}{|c|c|c|c|c|c|c|}
\hline \multirow{2}{*}{$\begin{array}{l}\text { Sample I.D. (Cement } \\
\text { Content in \%) }\end{array}$} & \multirow{2}{*}{$\begin{array}{l}\text { Total } \\
\text { Porosity } \\
(\%)\end{array}$} & \multicolumn{3}{|c|}{ Porosity in the first three pore ranges } & \multirow{2}{*}{$\begin{array}{l}\text { Total porosities in } \\
\text { the first three pore } \\
\text { regions }(\%)\end{array}$} & \multirow[b]{2}{*}{$\begin{array}{c}\text { E-value at } 6 \\
\text { months }\end{array}$} \\
\hline & & $\begin{array}{c}\text { Inter-Nano } \\
\text { pores }(\%)\end{array}$ & $\begin{array}{c}\text { Super-Nano pores } \\
(\%)\end{array}$ & $\begin{array}{l}\text { Sub-Micro } \\
\text { pores }(\%)\end{array}$ & & \\
\hline \multicolumn{7}{|c|}{ Reference Sample (L13-6M) } \\
\hline L13-6M (0) & 23.41 & 0.10 & 1.43 & 11.21 & 12.74 & 206.46 \\
\hline \multicolumn{7}{|c|}{ Other Samples } \\
\hline LC31-6M (25) & 30.03 & 0.00 & 2.29 & 9.64 & 11.93 & 487.68 \\
\hline LC21-6M (33) & 23.43 & 1.29 & 8.64 & 19.54 & 29.47 & 524.16 \\
\hline LC11-6M (50) & 25.66 & 0.64 & 8.64 & 23.72 & 33.00 & 671.52 \\
\hline LC12-6M (66) & 20.81 & 1.99 & 12.53 & 30.03 & 44.55 & 691.50 \\
\hline LC13-6M (75) & 21.45 & 2.02 & 15.11 & 33.32 & 50.45 & 780.83 \\
\hline
\end{tabular}

As mortar's Modulus of Elasticity is a function of its flexibility, the lower the E-value, the higher the flexibility. Fig. 11 therefore shows comparative tendencies of the mortars to exhibit flexibility, relative to the reference sample, L13. It could be observed that the cumulative porosity across the first three pore regions in a mortar is proportional to cement content and the E-value, as the pattern is illustrated using dotted arrow in Fig. 11.

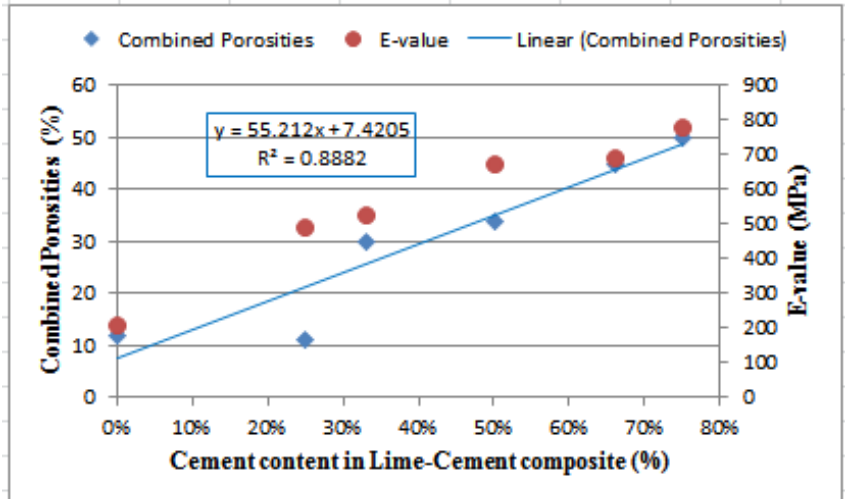

Fig. 11. Relationship between cement content, extracted MIP data and E-values for lime and lime-cement mortars.

From Fig. 11, it can be observed that the lower the cumulative porosity, the lower the E-value, thus higher flexibility (and vice versa). This observation is also supported by the apparent linear coefficient of correlation $\left(\mathrm{R}^{2}=0.89\right)$ for the equation describing both 'cumulative porosity' (within the referenced three pore ranges) and cement content. This relationship can be expressed as:

$$
\mathrm{C}_{\mathrm{P}}=55.212 \mathrm{c}+7.421
$$

where $\mathrm{C}_{\mathrm{P}}$ represents cumulative porosity, and $\mathrm{c}$ represents cement content.

Thus, it could be inferred that the mortars would exhibit flexibility in the descending order of LC31, LC21, LC11, LC12 and LC13 for lime-cement composites (with LC13 being the least flexible i.e., with the highest E-value of $780.83 \mathrm{MPA}$ ) as shown in Fig. 11. These results were expected, as composites with highest lime contents (i.e., LC31) was expected to exhibit highest flexibility in limecement composite. It could therefore be demonstrated that the pore structure, as defined by the volume of mercury intrusion into the specimen, across the three low pore regions of Inter-Nano pores $(1-10 \mathrm{~nm})$, Super-Nano pores $(10-100 \mathrm{~nm})$ and Sub-Micro pores $(0.1-1 \mu \mathrm{m})$ of limecement composite is a function of the composite's flexibility. The cumulative porosity across the three low pore regions has been shown to be synonymous with low (fc/ff), thereby defining a measure of flexibility. Accordingly, the composites have shown to exhibit more flexibility in the descending order of cement content. 


\section{CONCLUSION}

This study attempted to evaluate pore structures of lime composites in order to determine lime based mortars' flexibility tendencies. This is particularly useful in reviving sustainable eco-friendly lime based mortars relative to predominant polymer based cementitious products. Using 'lime-cement' composites, efforts are being made to evolve low carbon composite construction materials, with cement serving as a partial replacement for lime in each case. This is particularly useful with a view to promoting flexibility property of age-long building lime, known for its building structural failure accommodation. While the flexibility property of lime in the composites (via their pore structures) is explored, addition of cement to lime, to form a composite, increases lime's both compressive and flexural strengths. This is however characterized with reduced flexibility, subject to the cement content in the composite.

\section{CONFLICT OF INTEREST}

The author declares no conflict of interest.

\section{ACKNOWLEDGEMENTS}

The author wishes to acknowledge the financial support from 'TETFUND AST\&D' Scheme, an educational development organ of The Federal Government of Nigeria. Also, Hanson Cement, United Kingdom, is appreciated for the provision of cement used for this work.

\section{REFERENCES.}

[1] J. Lanas, J. L. Pérez Bernal, M. A. Bello, and J. I. Alvarez Galindo, "Mechanical properties of natural hydraulic lime-based mortars," Cement and Concrete Research, vol. 34(12), pp. 2191-2201, 2004.

[2] M. Arandigoyen, and J. I. Alvarez, "Pore structure and mechanical properties of cement-lime mortars," Cement and Concrete Research, 37(5), 767-775, 2007.

[3] J. Hughes, J. E. Lindqvist, CBI Betonginstitutet AB, SP - Sveriges Tekniska Forskningsinstitut, and RISE. "RILEM TC 203-RHM: Repair mortars for historic masonry: The role of mortar in masonry: An introduction to requirements for the design of repair mortars," Materials and Structures, 45(9), 1287-1294, 2012.

[4] S. A. Olaniyan, "Impact of Changing Microstructural Compositions of Lime Based Mortar on Flexibility: Case Study of Sustainable Lime-Cement Composites," Advances in Science, Technology and Engineering Systems Journal, Vol. 5, No. 6, 1488-1498, 2020a (https://astesj.com/v05/i02/p99/).

[5] S. Pavía, and E. Treacy, "A comparative study of the durability and behaviour of fat lime and feebly-hydraulic lime mortars," Materials and Structures, 39(3), 391-398, 2007.

[6] R. Hanley, and S. Pavía "A study of the workability of natural hydraulic lime mortars and its influence on strength," Materials and Structures, 41(2), 373-381, 2008.

[7] S. Pavia, and O. Brennan, "Portland cement-lime mortars for conservation," Proceedings of 3rd Historic Mortars Conference (HMC13), held at the University of the West of Scotland Glasgow, Scotland, 2013.

[8] A. M. Forster, "An assessment of the relationship between the water vapour permeability and hydraulicity of lime based mortars with particular reference to building conservation materials science," $\mathrm{PhD}$ Thesis, Heriot-Watt University, Edinburgh, 2002.

[9] A. Isebaert, W. De Boever, V. Cnudde, \& L. Van Parys, "An empirical method for the estimation of permeability in natural hydraulic lime mortars," Materials and Structures, 49(11), 4853 4865, 2016.

[10] P. F. G. Banfill, "Rheological methods for assessing the flow properties of mortar and related materials," Construction and Building Materials, 8(1), 43-50, 1994.
[11] L. Mcdonald, "Hydraulic lime mortar for the house of the future," The Structural Engineer, 78 (7), 2000.

[12] A. Solak, "Experimental investigation of lime mortar used in historical buildings in Becin, Turkey," Materials Science, 22(1), 105 112,2016

[13] A. J. Edwards, "Properties of hydraulic and non-hydraulic limes for use in construction," $\mathrm{PhD}$ Thesis, Napier University, Edinburgh, 2005.

[14] R. J. Ball, A. El-Turki, W. J. Allen, J. A. Nicholson, and G. C. Allen, "Deformation of NHL3.5 and CL90/PC hybrid mortars," Proceedings of the Institution of Civil Engineers - Construction Materials, 162(1), 29-35, 2009.

[15] S. A. Olaniyan, and A. J. Klemm, "Current Trends in Development of Lime Based Composites," Building Physics in Theory and Practice, Volume VII, No.3, pp 49-54, 2015.

[16] G. Cultrone, E. Sebastián, and M. O. Huertas, "Forced and natural carbonation of lime-based mortars with and without additives: Mineralogical and textural changes," Cement and Concrete Research, 35(12), 2278-2289, 2005.

[17] A. M. Forster, and K. Carter, "A framework for specifying natural hydraulic lime mortars for masonry construction" Structural Survey, 29(5), 373-396, 2011.

[18] A. Arizzi, H. Viles, and G. Cultrone, "Experimental testing of the durability of lime-based mortars used for rendering historic buildings," Construction and Building Materials, 28(1), 807-818, 2012.

[19] A. J. Klemm, and D. E. Wiggins, "Lime mortar and sacrificial protection of heritage stonework," Proceedings of the Institution of Civil Engineers - Engineering History and Heritage, 168(4), 167-176, 2015.

[20] L. Ventola, M. Vendrell, and P. Giraldez, "Newly-designed traditional lime mortar with a phase change material as an additive," Construction and Building Materials, 47, 1210-1216, 2013.

[21] F. Pacheco-Torgal, J. Faria, and S. Jalali, "Some considerations about the use of lime-cement mortars for building conservation purposes in portugal: A reprehensible option or a lesser evil?," Construction and Building Materials, 30(1), 488-494, 2012

[22] A. Izaguirre, J. Lanas, and J. I. Alvarez, "Effect of a polypropylene fibre on the behaviour of aerial lime-based mortars," Construction and Building Materials, 25(2), 992-1000, 2011.

[23] M. J. Mosquera, B. Silva, B. Prieto, and E. Ruiz-Herrera, "Addition of cement to lime-based mortars: effect on pore structure and vapor transport," Cement and Concrete Research, 36, 1635-1642, 2006.

[24] R. J. Ball, A. El-Turki, W. J. Allen, J. A. Nicholson, and G. C. Allen, "Deformation of NHL3.5 and CL90/PC hybrid mortars," Proceedings of the Institution of Civil Engineers - Construction Materials, 162(1), 29-35, 2009

[25] M. Tate, "The most important property of cement-lime mortar in masonry construction," Proceedings of International Building Lime Symposium, Orlando, Florida, March 9-11, 2005.

[26] C. Torney, and A. M. Forster, "Concerned with compatibility," Building Surveying Journal, 28, 2015.

[27] C. Torney, A. M. Forster, and E. M. Szadurski, "Specialist 'restoration mortars' for stone elements: A comparison of the physical properties of two stone repair materials," Heritage Science, 2(1), 1$12,2014$.

[28] S. A. Olaniyan, "Sustainable Lime Based Mortars: Performance Assessment of Composites for Building Construction" PhD Thesis, Glasgow Caledonian University, Glasgow, Scotland (UK), 2017.

[29] A. Moropoulou, "Reverse engineering: a proper methodology for compatible restoration mortars," RILEM Conference Proceedings on Historic Mortars, Delft, 2005.

[30] British Standards Institution (BSI) BS EN 13139, “Aggregates for mortar - Part 3 (PD 6682): Guidance on the use of Aggregates," British Standards, 2013.

[31] ASTM C136, "American Society for Testing and Materials Standard Test Method for particle size distributions," ASTM Standard, 2014.

[32] ASTM C 33, "American Society for Testing and Materials Standard Specification for mortar Aggregates," ASTM Standard, 2016.

[33] British Standards Institution (BSI) BS EN 1015 "Methods of Test for Mortar for Masonry - Part 3: Determination of Consistence of Fresh Mortar (by Flow Table)," British Standards, 2000.

[34] J. Lanas, and J. I. Alvarez-Galindo, "Masonry repair lime-based mortars: Factors affecting the mechanical behaviour," Cement and Concrete Research, 33(11), 1867-1876, 2003.

[35] A. Moropoulou, A. S. Cakmak, G. Biscontin, A. Bakolas, and E Zendri, "Advanced byzantine cement based composites resisting earthquake stresses: The crushed brick/lime mortars of justinian's hagia Sophia," Construction and Building Materials, 16(8), 543-552, 2002 . 
[36] British Standards Institution (BSI) BS EN 1015, "Methods of Test for Mortar for Masonry - Part 6: Determination of Bulk Density of Fresh Mortar," British Standards, 1999.

[37] British Standards Institution (BSI) PD 6678, "Published Document Guide to the Specification of the Masonry Mortar," British Standards, 2005.

[38] S. A. Olaniyan, "Low Carbon Sustainable Building Material: Maximising Slag potentials for improved lime mortar mechanical properties," Advances in Science, Technology and Engineering Systems Journal, Vol. 5, No. 2, 786-794, 2020b (https://astesj.com/v05/i02/p99/).

[39] British Standards Institution (BSI) "PD 6697: Published Document Recommendations for the Design of Masonry Structures to BS EN 1996-1-1 and BS EN 1996-2, British Standards, 2010.

[40] J. S. Pozo-Antonio, "Evolution of mechanical properties and drying shrinkage in lime-based and lime cement-based mortars with pure limestone aggregate," Construction and Building Materials, 77, 472478,2015

[41] E. A. W. Hendry, "Masonry walls: material and construction," Construction and Building Materials, 15, 323-330, 2001.

[42] K. M. Green, M. A. Carter, W. D. Hoff, and M. A. Wilson (1999). The effects of lime and admixtures on the water-retaining properties of cement mortars," Cement and Concrete Research, 29(11), 1743 1747, 1999.

[43] Y. Sébaïbi, R. M. Dheilly, B. Beaudoin, and M. Quéneudec, "The effect of various slaked limes on the microstructure of a limecement-sand mortar," Cement and Concrete Research, 36(5), 971978, 2006.

[44] K. Aligizaki, "Pore Structure of Cement-Based Materials: Testing, Interpretation and Requirements," Taylor and Francis, 2006.

[45] J. Grilo, P. Faria, R. Veiga, A. S. Silva, V. Silva, and A. Velosa, "New natural hydraulic lime mortars - physical and microstructura properties in different curing conditions," Construction and Building Materials, 54, pp 378-384, 2014.

[46] G. Land, and D. Stephan, "Controlling cement hydration with nanoparticles," Cement and Concrete Comp., 57, 64-67, 2015.

[47] Y. C. Choi, Y. K. Cho, K. Shin, and S. Kwon, "Development and application of microcapsule for cement hydration control," KSCE Journal of Civil Engineering, 20(1), 282-292, 2015.

[48] B. S. Briccoli, and L. Rovero, "Gli additivi per malte usati nell' antichita," Ed. Mascolo G, Materiali e tecniche per il Restauro Cassino. Idea Stampa Editore AIMAT, INISM, 1997.

[49] A. Moropoulou, A. Bakolas, P. Moundoulas, E. Aggelakopoulou, and S. Anagnostopoulou, "Strength development and lime reaction in mortars for repairing historic masonries," Cement and Concrete Comp., 27(2), pp 289-294, 2005.

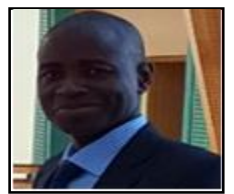

S. A. Olaniyan is a Senior Lecturer at the Department of Architecture, Ladoke Akintola University of Technology, Ogbomoso, Nigeria. He holds Masters' Degrees in Architecture from Nigeria and Sheffield, and a PhD degree in Sustainable Building Material in Lime-based Composites from Glasgow. He is a fully registered Architect with The Nigerian Institute of Architects, and Architects Registration Council of Nigeria. His research interests lie in Sustainable Building Materials and Development as a response to the phenomenal Climate Change. He is proficient in AutoCAD, Building Information Modelling, and Simulation software (inclusive of Revit Architecture, Designbuilder, among others). $\mathrm{He}$ is also familiar with scientific procedures involving evaluations of materials' mechanical properties, microstructural features (Porosimetry), particle size distribution (Difractometry), chemical compositions (Energy Dispersive Spectrometry) and thermal conductivity. He is the author of a Technical Textbook, Fundamental Procedures in AutoCAD Drafting (2005). He has been a recipient of some academic Awards and Scholarships. 